\title{
TITLE PAGE \\ Title: Markers Of Coagulation And Hemostatic Activation Identify COVID-19 Patients At High Risk For Thrombotic Events, ICU Admission and Intubation
}

Authors: Darwish Alabyad MS, Srikant Rangaraju MBBS, Michael Liu MD, Rajeel Imran MD, Christine L. Kempton MD, MSc, Milad Sharifpour MD, Sara C. Auld MD, MSC, Manila Gaddh MD, Roman Sniecinski MD, MSc, Cheryl L. Maier MD, PhD, Jeannette Guarner MD, Alexander Duncan MD, and Fadi Nahab MD.

\section{Author Affiliations:}

1. Darwish Alabyad, MS

Morehouse School of Medicine, Atlanta, GA

2. Srikant Rangaraju M.B.B.S.

Department of Neurology

Emory University School of Medicine, Atlanta, GA

3. Michael Liu M.D.

Department of Neurology

Emory University School of Medicine, Atlanta, GA

4. Rajeel Imran, M.D.

Department of Neurology

Emory University School of Medicine, Atlanta, GA

5. Christine L Kempton M.D. M.Sc.

Department of Hematology and Medical Oncology

Emory University School of Medicine, Atlanta, GA

6. Milad Sharifpour M.D.

Department of Anesthesiology, Division of Critical Care Medicine

Emory University School of Medicine, Atlanta, GA

7. Sara C. Auld M.D., M.Sc.

Emory Critical Care Center

Division of Pulmonary, Allergy, Critical Care, and Sleep Medicine, Department of Medicine,

Emory University School of Medicine, Atlanta, GA

Department of Epidemiology, Emory University Rollins School of Public Health

8. Manila Gaddh M.D.

Department of Hematology and Medical Oncology

Emory University School of Medicine, Atlanta, GA

9. Roman Sniecinski M.D., M.Sc.

Department of Anesthesiology

Emory University School of Medicine, Atlanta, GA 
1

2

3

4
10. Cheryl L. Maier M.D., Ph.D.

Department of Pathology and Laboratory Medicine

Emory University School of Medicine, Atlanta, GA

11. Jeannette Guarner, MD

Department of Pathology and Laboratory Medicine

Emory University School of Medicine, Atlanta, GA

12. Alexander Duncan, MD

Department of Pathology and Laboratory Medicine

Emory University School of Medicine, Atlanta, GA

13. Fadi Nahab M.D. (corresponding author)

Department of Neurology \& Pediatrics

Emory University, Atlanta, GA

Address: 1365 Clifton Road, Clinic B, Suite 2200, Atlanta, GA 30322

Fax: 404-778-3118

Phone: 404-727-1772

Email: fnahab@emory.edu

Total word count: 3231

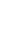

5

6

7

8

9

0


medRxiv preprint doi: https://doi.org/10.1101/2020.10.04.20206540; this version posted October 6, 2020. The copyright holder for this preprint (which was not certified by peer review) is the author/funder, who has granted medRxiv a license to display the preprint in perpetuity.

It is made available under a CC-BY-NC-ND 4.0 International license .

\section{ABSTRACT}

Background - Coronavirus disease 2019 (COVID-19) has been associated with a coagulopathy giving rise to venous and arterial thrombotic events. The objective of our study was to determine whether markers of coagulation and hemostatic activation (MOCHA) on admission could identify COVID-19 patients at risk for thrombotic events and other complications.

Methods - COVID-19 patients admitted to a tertiary academic healthcare system from April 3, 2020 to July 31, 2020 underwent standardized admission testing of MOCHA profile parameters (plasma d-dimer, prothrombin fragment 1.2, thrombin-antithrombin complex, and fibrin monomer) with abnormal MOCHA defined as $\geq 2$ markers above the reference. Prespecified thrombotic endpoints included deep vein thrombosis, pulmonary embolism, myocardial infarction, ischemic stroke, and access line thrombosis; other complications included ICU admission, intubation and mortality. We excluded patients on anticoagulation therapy prior to admission and those who were pregnant.

Results - Of 276 patients (mean age $59 \pm 6.4$ years, 47\% female, 62\% African American race) who met study criteria, $45(16 \%)$ had a thrombotic event. Each coagulation marker on admission was independently associated with a vascular endpoint $(\mathrm{p}<0.05)$. Admission MOCHA with $\geq 2$ abnormalities ( $\mathrm{n}=203,74 \%)$ was associated with in-hospital vascular endpoints (OR 3.3, 95\% CI 1.2-8.8), as were admission D-dimer $\geq 2000 \mathrm{ng} / \mathrm{mL}$ (OR 3.1, 95\% CI 1.5-6.6), and admission Ddimer $\geq 3000 \mathrm{ng} / \mathrm{mL}$ (OR 3.6, 95\% CI 1.6-7.9). However, only admission MOCHA with $\geq 2$ abnormalities was associated with ICU admission (OR 3.0, 95\% CI 1.7-5.2) and intubation (OR 3.2, 95\% CI 1.6-6.4), while admission D-dimer $\geq 2000 \mathrm{ng} / \mathrm{mL}$ and admission D-dimer $\geq 3000$ ng/mL were not associated. MOCHA and D-dimer cutoffs were not associated with mortality. 
medRxiv preprint doi: https://doi.org/10.1101/2020.10.04.20206540; this version posted October 6, 2020. The copyright holder for this preprint (which was not certified by peer review) is the author/funder, who has granted medRxiv a license to display the preprint in perpetuity. It is made available under a CC-BY-NC-ND 4.0 International license.

1 Admission MOCHA with $<2$ abnormalities (26\% of the cohort) had a sensitivity of $88 \%$ and

2 negative predictive value of $93 \%$ for a vascular endpoint.

3 Conclusions - Admission MOCHA with $\geq 2$ abnormalities identified COVID-19 patients at

4 increased risk of ICU admission and intubation during hospitalization more effectively than

5 isolated admission D-dimer measurement. Admission MOCHA with <2 abnormalities identified

6 a subgroup of patients at low risk for vascular events. Our results suggest that an admission

7 MOCHA profile can be useful to risk-stratify COVID-19 patients. 
medRxiv preprint doi: https://doi.org/10.1101/2020.10.04.20206540; this version posted October 6, 2020. The copyright holder for this preprint (which was not certified by peer review) is the author/funder, who has granted medRxiv a license to display the preprint in perpetuity.

It is made available under a CC-BY-NC-ND 4.0 International license .

\section{1}

\section{INTRODUCTION}

2 Coronavirus disease 2019 (COVID-19) has been widely associated with the development of a

3 systemic coagulopathy that is likely multifactorial in etiology. ${ }^{1}$ COVID-19-associated

4 coagulopathy exhibits the classic components of Virchow's triad, and there are ongoing efforts to

5 better characterize the underlying pathophysiology of the hypercoagulable state in the setting of

6 COVID-19 infection. ${ }^{2}$ Elevated levels of fibrin degradation products, particularly D-dimer, have

7 been used to predict venous thromboembolic events (VTE) and hypercoagulable states in various

8 disease states. ${ }^{3,4}$ Plasma D-dimer in COVID-19 patients was found to be a useful predictor of

$9 \mathrm{VTE}^{5,6}$ and thresholds of $2000 \mathrm{ng} / \mathrm{mL}$ or $3000 \mathrm{ng} / \mathrm{mL}$ have been suggested as indicators of

10 disease severity. ${ }^{7,8}$

11 A biomarker panel called the markers of coagulation and hemostatic activation (MOCHA),

12 which includes plasma D-dimer, prothrombin fragment 1.2, thrombin-antithrombin complex and

13 fibrin monomer levels, has been shown to predict subsequent diagnosis of new malignancy,

14 VTE, and other hypercoagulable states in patients with cryptogenic stroke. ${ }^{9,10}$ A previous study

15 has also demonstrated that a MOCHA profile with < 2 marker abnormalities can effectively rule

16 out hypercoagulable states in patients with embolic stroke of undetermined source. ${ }^{11}$

17 The objective of this study was to determine whether the admission MOCHA profile in

18 hospitalized COVID-19 patients could aid in risk stratification by identifying those patients at

19 low versus high risk of vascular thrombotic events, ICU admission, intubation and clinical

20 outcome more effectively than D-dimer alone.

\section{METHODS}

22 Study Design and Setting 
medRxiv preprint doi: https://doi.org/10.1101/2020.10.04.20206540; this version posted October 6, 2020. The copyright holder for this preprint (which was not certified by peer review) is the author/funder, who has granted medRxiv a license to display the preprint in perpetuity.

It is made available under a CC-BY-NC-ND 4.0 International license .

1 Patients were prospectively identified from an admission census list that identified all COVID-19

2 patients admitted to four hospitals in Emory Healthcare, an urban, academic, tertiary healthcare

3 system in Atlanta, Georgia who had a MOCHA profile ordered on admission as part of a

4 standardized COVID-19 orderset from April 3, 2020 through July 31, 2020. Expert consensus of

5 a multidisciplinary working group recommended obtaining a MOCHA profile on all patients

6 admitted with a diagnosis of COVID-19. All patients were 18 years of age or older with

7 diagnosis of COVID-19 confirmed by PCR and had a MOCHA profile drawn within 72 hours of

8 hospitalization. For this analysis we excluded patients on outpatient anticoagulation therapy prior

9 to hospitalization due to the effect of anticoagulation on the MOCHA profile ${ }^{10}$ and pregnant patients due to the lack of validated reference ranges. Electronic medical records were

11 retrospectively reviewed from admission through discharge or until the censor date of September

1214,2020 to identify venous and arterial thrombotic events. This study was approved by the

13 Emory University Institutional Review Board.

14 Patient demographics including age, sex, race, body mass index (BMI), and a history of

15 comorbidities including smoking, diabetes, hypertension, asthma, chronic obstructive pulmonary

16 disorder (COPD), human immunodeficiency virus (HIV) infection, end stage renal disease, atrial

17 fibrillation, prior VTE, coronary artery disease (CAD), stroke, and known active cancer were

18 collected. Total length of stay, length of intensive care unit (ICU) admission, length of

19 intubation, and final disposition were additionally recorded. Prespecified venous and arterial

20 endpoints monitored during hospitalization included deep vein thromboses (DVT), pulmonary

21 embolus (PE), myocardial infarction (MI), ischemic stroke, and dialysis or central line clots.

22 DVT was confirmed by duplex ultrasound and PE by CT, CT angiography or

23 ventilation/perfusion scans. MI was diagnosed as a troponin elevation and confirmation by a 
medRxiv preprint doi: https://doi.org/10.1101/2020.10.04.20206540; this version posted October 6, 2020. The copyright holder for this preprint (which was not certified by peer review) is the author/funder, who has granted medRxiv a license to display the preprint in perpetuity.

It is made available under a CC-BY-NC-ND 4.0 International license .

1 board-certified cardiologist. Ischemic stroke was diagnosed by CT or MRI and confirmation by a

2 board-certified neurologist. Central access and renal replacement therapy circuit thrombosis were

3 determined based on chart documentation.

4

$5 \quad$ Laboratory testing

6 Admission MOCHA profiles were obtained within 72 hours of hospitalization and included

7 plasma levels of D-dimer (reference value $<574 \mathrm{ng} / \mathrm{mL}$ ), prothrombin fragment 1.2 (reference

8 range $65-288 \mathrm{pmol} / \mathrm{L}$ ), thrombin-antithrombin complex (reference range 1.0-5.5 $\mu \mathrm{g} / \mathrm{L}$ ), and

9 fibrin monomer (reference value $<7 \mu \mathrm{g} / \mathrm{mL}$ ). All assays were performed in the hospital clinical

10 laboratories using 3.2\% citrated plasma specimens. D-dimer levels were measured with high-

11 sensitivity latex dimer assay (Instrumentation Laboratories, Bedford, MA). Both prothrombin

12 fragment 1.2 and thrombin-antithrombin complexes were measured with the Enzygnost ELISA

13 kit (Siemens Healthcare, Tarrytown, NY). Soluble fibrin monomer levels were measured by

14 latex immunoassay (Stago, Parsippany, NJ).

17 Descriptive statistics were used to summarize the data with results reported as percentages for

18 categorical variables. Means with standard deviations or medians with interquartile ranges were

19 reported for normally distributed and skewed variables, respectively. Comparisons between

20 means or medians of continuous variables were assessed with independent T-tests (two-tailed) or

21 by the Mann-Whitney U non-parametric test, respectively. Categorical variables were compared

22 with Pearson's chi-square and Fisher Exact tests. Significance for all descriptive analyses was set 
medRxiv preprint doi: https://doi.org/10.1101/2020.10.04.20206540; this version posted October 6, 2020. The copyright holder for this preprint (which was not certified by peer review) is the author/funder, who has granted medRxiv a license to display the preprint in perpetuity.

It is made available under a CC-BY-NC-ND 4.0 International license .

1 at $\mathrm{p}<0.05$. Univariable analyses were conducted using binary logistic regression for binary

2 outcome variables (vascular endpoint, VTE, ICU admission, intubation and mortality).

3 Statistically significant predictors of these outcomes $(\mathrm{p}<0.10)$ were then considered in

4 multivariable binary logistic regression analyses to identify independent outcome predictors

5 (adjusted $\mathrm{p}<0.05$ ). The association with thrombotic events within 14 days of admission was

6 additionally examined.

7 The frequency of D-dimer and MOCHA profile abnormalities were recorded and subsequently

8 analyzed in specific patient subsets, including those with ICU admission and intubation. The four

9 parameters of the MOCHA profile were independently assessed using receiver operator

10 characteristic (ROC) curve analysis in order to determine the area under the curve (AUC) as a

11 measure of discriminative power. Patients were stratified based on the number of elevated

12 MOCHA markers on admission. Sensitivity, specificity, positive predictive value (PPV), and

13 negative predictive value (NPV) were evaluated at different MOCHA and D-dimer cutoffs. This

14 was used to identify optimal thresholds for predicting thrombotic endpoints and to compare the

15 performance of admission MOCHA with admission D-dimer alone. Statistical analyses and

16 figures were generated using SPSS version 26 software.

\section{RESULTS}

20 A total of 297 confirmed COVID-19 patients were hospitalized during the study period and had

21 MOCHA profile within 72 hours of admission. After exclusion of 18 patients on outpatient

22 anticoagulation therapy and three pregnant patients, the analysis cohort included 276 patients. 
medRxiv preprint doi: https://doi.org/10.1101/2020.10.04.20206540; this version posted October 6, 2020. The copyright holder for this preprint (which was not certified by peer review) is the author/funder, who has granted medRxiv a license to display the preprint in perpetuity.

It is made available under a CC-BY-NC-ND 4.0 International license .

1 The mean age of the cohort was $59 \pm 6$ years, $130(47 \%)$ were female, and $160(62 \%)$ were

2 African American. Median BMI was 30 (IQR: 26-37) kg/m² (Table 1). Common comorbidities

3 included hypertension (59\%), obesity $(n=140,51 \%)$ and diabetes $(n=108,39 \%)$. The median

4 duration of hospitalization was 10 days (IQR: 6-19) including 159 patients (58\%) admitted to the

5 ICU during their hospitalization, 90 (33\%) who were intubated. Amongst the cohort, $241(87 \%)$

6 patients were discharged, $31(11 \%)$ died and $4(1 \%)$ remained hospitalized as of the censor date.

\section{$7 \quad$ Frequency of Vascular Events}

8 Vascular events were diagnosed in 45 patients (16\%) (Table 2). Median number of days to

9 diagnosis of vascular event was 7 days (IQR: 2-15) from admission, with 32 (71\%) of these

10 events occurring within the first two weeks of hospitalization. DVT occurred in $24(8.7 \%)$

11 patients, PE in 8 (2.9\%), MI in 4 (1.5\%), ischemic stroke in 5 (1.8\%) and central or dialysis line

12 thrombosis in $7(2.5 \%)$ patients; three patients (1\%) developed more than one of these

13 complications.

14 Overall, 7 (2.5\%) patients had no MOCHA abnormalities on admission, 66 (24\%) had one

15 abnormality, $62(23 \%)$ had two abnormalities, 69 (25\%) had three abnormalities, and $72(26.1 \%)$

16 had abnormalities in all four MOCHA; 217 patients (79\%) had an abnormal D-dimer on

17 admission, 51 (19\%) had an admission D-dimer greater than $2000 \mathrm{ng} / \mathrm{mL}$, and 40 (15\%) had an

18 admission D-dimer greater than $3000 \mathrm{ng} / \mathrm{mL}$. There were $115(42 \%)$ patients who had an

19 elevated prothrombin fragment 1.2 level, 185 (67\%) with an elevated thrombin-antithrombin

20 complex level, and 167 (61\%) with elevated fibrin monomer levels. The frequency of thrombotic

21 events, ICU admission and intubation rates progressively increased with the number of MOCHA

22 abnormalities (Figure 1). 
medRxiv preprint doi: https://doi.org/10.1101/2020.10.04.20206540; this version posted October 6, 2020. The copyright holder for this preprint (which was not certified by peer review) is the author/funder, who has granted medRxiv a license to display the preprint in perpetuity.

It is made available under a CC-BY-NC-ND 4.0 International license .

3 In univariable analysis admission MOCHA $\geq 2$ abnormalities, D-dimer $\geq 2000$ ng/mL, D-dimer

$4 \geq 3000 \mathrm{ng} / \mathrm{mL}, \mathrm{BMI}$, and CAD were significantly associated with vascular events. However, in

5 multivariable analysis only MOCHA $\geq 2$ (OR 3.3, 95\% CI 1.2-8.8; p=.02), BMI (OR 1.04, 95\%

6 CI 1.0-1.1; $\mathrm{p}=.03), \mathrm{D}-\mathrm{dimer} \geq 2000 \mathrm{ng} / \mathrm{mL}(\mathrm{OR} 3.1,95 \%$ CI 1.5-6.6; $\mathrm{p}=.003)$, and D-dimer $\geq$

$73000 \mathrm{ng} / \mathrm{mL}(\mathrm{OR} 3.6,95 \%$ CI 1.6-7.9; p=.002) were significant. In multivariable analysis,

8 factors associated with vascular events within 14 days of admission included male sex (OR 2.2,

9 95\% CI 1.0-5.0; $\mathrm{p}=.049)$, MOCHA $\geq 2$ abnormalities (OR 6.4, 95\% CI 1.5-27.6; p=.013) and D-

10 dimer $\geq 2000 \mathrm{ng} / \mathrm{mL}(\mathrm{OR} 2.5,95 \%$ CI 1.1-5.9; $\mathrm{p}=.03)$.

13 In univariable analysis, admission $\mathrm{MOCHA} \geq 2$ abnormalities and a history of stroke were

14 significantly associated with ICU admission. However, in multivariable analysis, only admission

15 MOCHA $\geq 2$ abnormalities was a significant predictor of ICU admission (OR 3.0, 95\% CI 1.7-

$16 \quad 5.2 ; \mathrm{p}=.0001)$

17 With regards to the risk of respiratory deterioration and intubation, BMI, history of hypertension,

18 and MOCHA $\geq 2$ abnormalities were associated with intubation in univariable analysis. In

19 multivariable analysis, MOCHA $\geq 2$ abnormalities (OR 3.2, 95\% CI 1.6-6.4; p=.001) and BMI

20 (OR 1.04, 95\% CI 1.0-1.1; p=.017) remained significant. D-dimer was not significantly

21 associated with either ICU admission or intubation. 
medRxiv preprint doi: https://doi.org/10.1101/2020.10.04.20206540; this version posted October 6, 2020. The copyright holder for this preprint (which was not certified by peer review) is the author/funder, who has granted medRxiv a license to display the preprint in perpetuity.

It is made available under a CC-BY-NC-ND 4.0 International license .

1 In univariable analysis, admission MOCHA $\geq 2$ abnormalities, history of stroke, hypertension,

2 diabetes and BMI were significantly associated with mortality. In multivariable analysis, only

3 BMI remained a significant predictor of mortality (OR 1.04, 95\% CI 1.01-1.08; $\mathrm{p}=0.02$ ).

4 Value of Admission MOCHA and D-dimer in Predicting Vascular Events, VTE, ICU Admission,

5 and Intubation

6 Sensitivity, specificity, PPV, and NPV at different MOCHA and D-dimer cutoffs are shown in

7 Table 3. A MOCHA profile with $\geq 2$ abnormalities had a sensitivity of $89 \%$ (NPV 93\%) for a

8 vascular thrombotic event through total hospitalization, 94\% (NPV 97\%) for a vascular

9 thrombotic event within two weeks of admission, and 96\% (NPV 99\%) for VTE within two

10 weeks of admission. D-dimer level $\geq 2000 \mathrm{ng} / \mathrm{mL}$ on admission had a sensitivity of $33 \%$ (NPV

$1187 \%$ ) for a vascular thrombotic event through total hospitalization, sensitivity of $31 \%$ (NPV

$1290 \%$ ) for a vascular thrombotic event within two weeks of admission and a sensitivity of $43 \%$

13 (NPV 94\%) for VTE within two weeks.

14 ROC curve analysis showed that all four MOCHA parameters were independent predictors of

15 any vascular endpoint $(\mathrm{p}<.01)$. However, the discriminative power for MOCHA was highest for

16 VTE within the first two weeks of admission, during which time D-dimer and thrombin-

17 antithrombin complex both had AUC 0.74, prothrombin fragment 1.2 had AUC 0.68 and fibrin

18 monomer AUC 0.62.

\section{DISCUSSION}

21 Our study provides systematic assessment of the admission MOCHA profile in hospitalized

22 COVID-19 patients and its association with vascular thrombotic events. While the frequency of 
medRxiv preprint doi: https://doi.org/10.1101/2020.10.04.20206540; this version posted October 6, 2020. The copyright holder for this preprint (which was not certified by peer review) is the author/funder, who has granted medRxiv a license to display the preprint in perpetuity.

It is made available under a CC-BY-NC-ND 4.0 International license .

1 elevated D-dimer and prothrombin fragment 1.2 is similar to those reported in recent studies ${ }^{7,12}$,

2 our study is the first to report the frequency of thrombin-antithrombin complex and fibrin

3 monomer levels in hospitalized COVID-19 patients. While $\geq 2$ abnormalities in the admission

4 MOCHA profile and D-dimer cutoffs were significantly associated with vascular thrombotic

5 events only the admission MOCHA profile was associated with subsequent ICU admission and

6 intubation whereas D-dimer cutoffs of $\geq 2000 \mathrm{ng} / \mathrm{mL}$ and $\geq 3000 \mathrm{ng} / \mathrm{mL}$ were not.

7 We assessed these four markers of coagulation and hemostatic activation given their prior

8 association with thrombotic events. ${ }^{9-11}$ D-dimer is a marker of fibrinolysis as a byproduct of

9 fibrin degradation. Prothrombin fragment 1.2 is a marker of coagulation activation and released

10 during conversion of prothrombin to thrombin. Thrombin-antithrombin complex is a marker of

11 coagulation activation and a complex formed during thrombin formation. Fibrin monomer

12 (soluble fibrin) is a marker of coagulation activation and a byproduct of fibrinogen conversion to

13 fibrin. $^{14}$

14 We found no association between admission MOCHA profile or admission D-dimer and

15 mortality, contrary to early studies from China which suggested that D-dimer was a predictor of

16 mortality in pooled analysis. ${ }^{13}$ There are several factors which may contribute to this difference:

17 1) our patients were all placed on prophylactic or therapeutic doses of anticoagulation therapy

18 according to our local guidelines which may have influenced overall mortality rates which are

19 lower in our cohort than other studies in the pooled analysis ${ }^{8}$; 2) the Chinese studies in this

20 pooled analysis were all retrospective cohorts and excluded patients who were still hospitalized

21 at the end of the study period contributing to a high risk of bias. ${ }^{13}$

22 Given current recommendations on the use of anticoagulation therapy in COVID-19 patients ${ }^{15}$,

23 we also sought to identify whether the MOCHA profile could identify a COVID-19 patient 
medRxiv preprint doi: https://doi.org/10.1101/2020.10.04.20206540; this version posted October 6, 2020. The copyright holder for this preprint (which was not certified by peer review) is the author/funder, who has granted medRxiv a license to display the preprint in perpetuity.

It is made available under a CC-BY-NC-ND 4.0 International license .

1 subgroup that was at low risk for vascular thrombotic events. In our cohort, $26 \%$ of patients on

2 admission had 0 or 1 MOCHA abnormality with NPV of $93 \%$ for vascular thrombotic events and

3 NPV of $95 \%$ for VTE. These data suggest that this patient subgroup is at low risk for subsequent

4 thrombotic complications.

5 This study had several limitations. As the data was collected from a single academic healthcare

6 system, the generalizability of these findings needs to be studied in other settings. Our study

7 focused on admission coagulation markers to aid in early risk stratification for COVID-19

8 patients however it is unknown whether serial measurements and changes in values across time

9 may be better predictors. Lastly, our study did not assess whether the MOCHA profile could be

10 used to guide anticoagulation therapy and how that may impact overall thrombotic events and

11 clinical outcome.

12 In summary, the admission MOCHA profile of hospitalized COVID-19 patients is useful in

13 identifying hospitalized patients who are at increased risk for subsequent arterial and venous

14 thrombotic events and more effectively identifies patients requiring ICU admission and

15 intubation than admission D-dimer levels alone. Further investigation is needed to determine the

16 utility of the MOCHA profile to guide anticoagulation therapy. 
medRxiv preprint doi: https://doi.org/10.1101/2020.10.04.20206540; this version posted October 6, 2020. The copyright holder for this preprint (which was not certified by peer review) is the author/funder, who has granted medRxiv a license to display the preprint in perpetuity.

It is made available under a CC-BY-NC-ND 4.0 International license .

\section{References:}

1. Iba T, Levy JH, Connors JM, Warkentin TE, Thachil J, Levi M. The unique characteristics of COVID-19 coagulopathy. Crit Care. 2020;24:360.

2. Ahmed S, Zimba O, Gasparyan AY. Thrombosis in Coronavirus disease 2019 (COVID19) through the prism of Virchow's triad. Clin Rheumatol. 2020;39(9):2529-2543.

3. Karsy M, Azab MA, Harper J, et al. Evaluation of a D-Dimer Protocol for Detection of Venous Thromboembolism. World Neurosurg 2020;133:e774-e783.

4. Shi A, Huang J, Wang X, et al. Postoperative D-dimer predicts venous thromboembolism in patients undergoing urologic tumor surgery. Urol Oncol. 2018;36:307.

5. Artifoni M, Danic G, Gautier G, et al. Systematic assessment of venous thromboembolism in COVID-19 patients receiving thromboprophylaxis: incidence and role of D-dimer as predictive factors. J Thromb Thrombolysis. 2020;50(1):211-216.

6. Cui S, Chen S, Li X, Liu S, Wang F. Prevalence of venous thromboembolism in patients with severe novel coronavirus pneumonia. J Thromb Haemost. 2020;18(6):1421-1424.

7. Yao, Y., Cao, J., Wang, Q., Shi Q., Liu K., Luo Z., Chen X., Chen S., Yu K., Huang Z. et al. D-dimer as a biomarker for disease severity and mortality in COVID-19 patients: a case control study. J Intensive Care 2020;8:1-11.

8. Guidelines for the Prevention and Treatment of VTE in Critically Ill Patients with COVID-19: https://www.emoryhealthcare.org/ui/pdfs/covid/medicalprofessionals/COVID\%20Emory\%20VTE\%20Guidelines\%2021May2020.pdf. Accessed October 3, 2020.

9. Nahab F., Sharashidze V., Liu M., Rathakrishnan P., El Jamal S., Duncan A. , Hoskins M., Marmarchi F., Belagaje S., Bianchi N. et al. Markers of coagulation and hemostatic 
medRxiv preprint doi: https://doi.org/10.1101/2020.10.04.20206540; this version posted October 6, 2020. The copyright holder for this preprint (which was not certified by peer review) is the author/funder, who has granted medRxiv a license to display the preprint in perpetuity.

It is made available under a CC-BY-NC-ND 4.0 International license .

activation aid in identifying causes of cryptogenic stroke. Neurology. 2020; 94 (18) e1892-e1899.

10. Ellis D, Rangaraju S, Duncan A, Hoskins M, Ali Raza S, Rahman H, Winningham M, Belagaje S, Bianchi N, Mohamed G et al. Coagulation markers and echocardiography predict atrial fibrillation, malignancy or recurrent stroke after cryptogenic stroke [published correction appears in Medicine (Baltimore). Medicine (Baltimore). 2018;97(51):e13830.

11. Liu M, Rangaraju S, Ellis D, Duncan A, Belagaje S, Belair T, Henriquez L, Nahab F. Abstract 28: Biomarkers of Coagulation and Hemostatic Activation in Post-Acute Period Effectively Rule Out Hypercoagulable States in Patients with Embolic Stroke of Undetermined Source. Stroke 2020;51:A27.

12. Al-Samkari H, Song, F, Van Cott, EM, Kuter, DJ, Rosovsky, R. Evaluation of the prothrombin fragment 1.2 in patients with coronavirus disease 2019 (COVID $\square$ 19). Am J Hematol. 2020; $1-7$.

13. Sakka M, Connors JM, Hekimian G, Martin-Toutain I, Crichi B, Colmegna I, BonnefontRousselot D, Farge D, Frere C. Journal de Medecine Vasculaire 2020;45:268-274.

14. Dati F, Pelzer H, Wagner C. Relevance of Markers of Hemostasis Activation in Obstetrics/Gynecology and Pediatrics. Seminars in Thrombosis and Hemostasis 1998; 24:443-448.

15. Spyropoulos AC, Levy JH, Ageno W, Connors JM, Hunt BJ, Iba T, Levi M, Samama CM, Thachill J, Giannis D. Scientific and Standardization Committee communication: Clinical guidance on the diagnosis, prevention, and treatment of venous 
medRxiv preprint doi: https://doi.org/10.1101/2020.10.04.20206540; this version posted October 6, 2020. The copyright holder for this preprint (which was not certified by peer review) is the author/funder, who has granted medRxiv a license to display the preprint in perpetuity.

It is made available under a CC-BY-NC-ND 4.0 International license.

1

thromboembolism in hospitalized patients with COVID $\square$ 19. J Thromb

2

Haemost. 2020;18:1859-1865.

3

4

5

6

7

8

9

10

11

12

13

14

15

16

17

18

19 
medRxiv preprint doi: https://doi.org/10.1101/2020.10.04.20206540; this version posted October 6, 2020. The copyright holder for this preprint (which was not certified by peer review) is the author/funder, who has granted medRxiv a license to display the preprint in perpetuity. It is made available under a CC-BY-NC-ND 4.0 International license.

1 Table 1. Patient characteristics and outcomes

\section{Characteristic $\quad$ Cohort $(\mathbf{n}=\mathbf{2 7 6})$}

\section{Demographics}

Age mean (SD)

$59(6.4)$

Female, n (\%)

$130(47)$

Race, n (\%)

African American

$160(58)$

Caucasian

45 (16)

Hispanic

44 (16)

Asian

9 (3)

Unspecified

$18(6.5)$

Median BMI (IQR)

$30(26-37)$

\section{Hospitalization Details}

Median Length of Stay (IQR) 10 (6-19)

Intubation, n (\%)

$90(33)$

ICU Admission, n (\%)

$158(57)$

Discharge Disposition, n (\%)

Home

$182(67)$

LTAC

$16(5.9)$

Acute/Inpatient Rehab

Subacute Rehab

Nursing Home/ALF

$27(9.9)$

Death

$31(11)$ 
medRxiv preprint doi: https://doi.org/10.1101/2020.10.04.20206540; this version posted October 6, 2020. The copyright holder for this preprint (which was not certified by peer review) is the author/funder, who has granted medRxiv a license to display the preprint in perpetuity.

It is made available under a CC-BY-NC-ND 4.0 International license .

\section{Comorbidities}

\begin{tabular}{cc}
\hline Smoker, ever, n (\%) & $60(24)$ \\
\hline Obese, n (\%) & $140(51)$ \\
\hline Diabetes, n (\%) & $108(39)$ \\
\hline Hypertension, n (\%) & $163(59)$ \\
\hline History of VTE, n (\%) & $3(1.1)$ \\
\hline Asthma, n (\%) & $25(9.1)$ \\
\hline COPD, n (\%) & $23(8.3)$ \\
\hline HIV, n (\%) & $15(5.4)$ \\
\hline ESRD on HD, n (\%) & $9(3.3)$ \\
\hline Atrial Fibrillation, n (\%) & $25(9.1)$ \\
\hline CAD, n (\%) & $19(6.9)$ \\
\hline Stroke, n (\%) & $8.9)$ \\
\hline Active Cancer, n (\%) & \\
\hline
\end{tabular}

1 Abbreviations: Body mass index (BMI). Intensive Care Unit (ICU). Long-term acute care

2 (LTAC). Assisted living facility (ALF). 
medRxiv preprint doi: https://doi.org/10.1101/2020.10.04.20206540; this version posted October 6, 2020. The copyright holder for this preprint (which was not certified by peer review) is the author/funder, who has granted medRxiv a license to display the preprint in perpetuity. It is made available under a CC-BY-NC-ND 4.0 International license.

Frequency*

\begin{tabular}{ccr}
\hline Outcomes & Entire & Within 14 D \\
& Hospitalization & \\
DVT, n (\%) & $24(8.7)$ & $17(6.2)$ \\
PE, n (\%) & $8(2.9)$ & $7(2.5)$ \\
MI, n (\%) & $4(1.5)$ & $2(0.7)$ \\
Ischemic Stroke, n $(\%)$ & $5(1.8)$ & $5(1.8)$ \\
Line Clot, n $(\%)$ & $7(2.5)$ & $32(11.6)$
\end{tabular}

$2 * 3$ patients developed more than one vascular endpoint

3 DVT=deep vein thrombosis; $\mathrm{PE}=$ pulmonary embolus; $\mathrm{MI}=$ myocardial infarction 
medRxiv preprint doi: https://doi.org/10.1101/2020.10.04.20206540; this version posted October 6, 2020. The copyright holder for this preprint (which was not certified by peer review) is the author/funder, who has granted medRxiv a license to display the preprint in perpetuity.

It is made available under a CC-BY-NC-ND 4.0 International license .

1 Figure 1. Frequency of MOCHA abnormalities in patients with vascular endpoints, intubation and ICU admission.

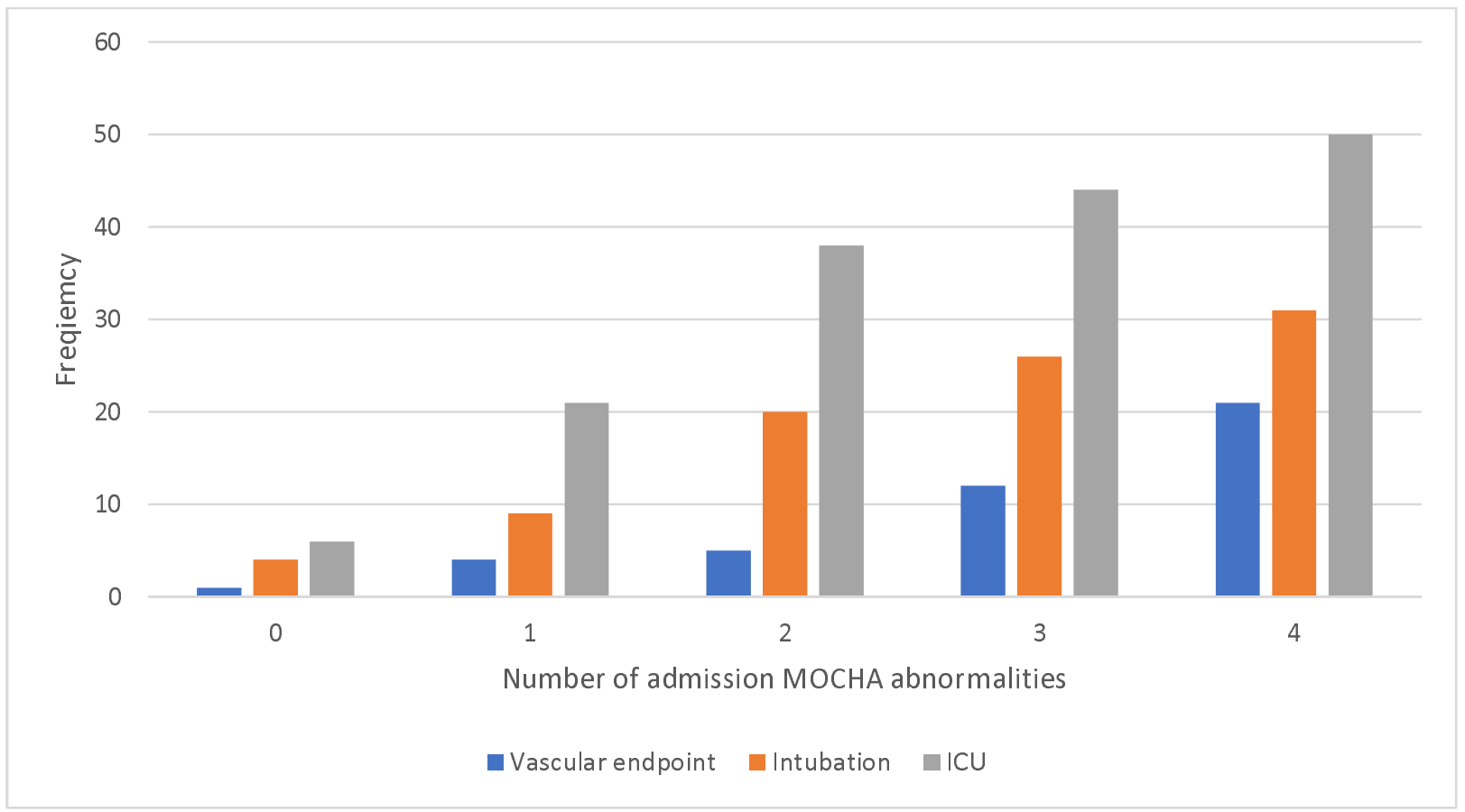


medRxiv preprint doi: https://doi.org/10.1101/2020.10.04.20206540; this version posted October 6, 2020. The copyright holder for this preprint (which was not certified by peer review) is the author/funder, who has granted medRxiv a license to display the preprint in perpetuity.

It is made available under a CC-BY-NC-ND 4.0 International license .

1 Table 3. Sensitivity, specificity, positive predictive value and negative predictive value for

2 (A) admission MOCHA and (B) D-dimer cutoffs with vascular endpoints.

\begin{tabular}{|c|c|c|c|c|}
\hline \multicolumn{5}{|c|}{ A. Admission MOCHA abnormalities } \\
\hline \multicolumn{5}{|c|}{ 1. Total vascular endpoint $(n=45)$} \\
\hline Threshold & Sensitivity & Specificity & PPV & NPV \\
\hline$\geq 0$ & 100 & 0 & 16.3 & \\
\hline$\geq 1$ & 97.8 & 2.60 & 16.4 & 85.7 \\
\hline$\geq 2$ & 88.8 & 29.4 & 19.7 & 93.2 \\
\hline$\geq 3$ & 77.8 & 54.1 & 24.8 & 92.6 \\
\hline 4 & 46.7 & 77.9 & 29.2 & 88.2 \\
\hline
\end{tabular}

2. Vascular endpoints $<14$ days from admission $(n=32)$

\begin{tabular}{ccccc} 
Threshold & Sensitivity & Specificity & PPV & NPV \\
\hline$\geq 0$ & 100 & 0 & 11.6 & \\
$\geq 1$ & 100 & 2.87 & 11.9 & 100 \\
$\geq 2$ & 93.8 & 29.1 & 14.8 & 97.3 \\
$\geq 3$ & 81.3 & 52.9 & 18.4 & 95.6 \\
4 & 40.6 & 75.8 & 18.1 & 90.7 \\
\hline
\end{tabular}

3. Total VTE $(n=31)$

\begin{tabular}{ccccc} 
Threshold & Sensitivity & Specificity & PPV & NPV \\
\hline$\geq 0$ & 100 & 0 & 11.2 & \\
$\geq 1$ & 96.8 & 2.45 & 11.2 & 85.7 \\
$\geq 2$ & 87.1 & 28.2 & 13.3 & 94.5 \\
$\geq 3$ & 77.4 & 52.2 & 17.0 & 94.8 \\
4 & 45.2 & 76.3 & 19.4 & 91.7 \\
\hline
\end{tabular}

4. VTE $<14$ days from admission ( $n=23)$

\begin{tabular}{ccccc} 
Threshold & Sensitivity & Specificity & PPV & NPV \\
\hline$\geq 0$ & 100 & 0 & 8.33 & \\
$\geq 1$ & 100 & 2.77 & 8.55 & 100 \\
$\geq 2$ & 95.7 & 28.5 & 10.8 & 98.6 \\
$\geq 3$ & 87.0 & 52.2 & 14.2 & 97.8 \\
4 & 47.8 & 75.9 & 15.3 & 94.1 \\
\hline
\end{tabular}

B. Admission D-dimer $(\mathrm{ng} / \mathrm{mL})$

1. Total vascular endpoint $(n=45)$

\begin{tabular}{ccccc} 
Threshold & Sensitivity & Specificity & PPV & NPV \\
\hline$\geq 2000 \mathrm{ng} / \mathrm{mL}$ & 33.3 & 84.4 & 29.4 & 86.7
\end{tabular}


$\geq 3000 \mathrm{ng} / \mathrm{mL}$

28.9

88.3

32.5

86.4

2. Vascular endpoints $<14$ days from admission $(n=32)$

\begin{tabular}{ccccc} 
Threshold & Sensitivity & Specificity & PPV & NPV \\
\hline$\geq 2000 \mathrm{ng} / \mathrm{mL}$ & 31.3 & 83.2 & 19.6 & 90.2 \\
$\geq 3000 \mathrm{ng} / \mathrm{mL}$ & 25.0 & 86.9 & 20.0 & 89.8
\end{tabular}

3. Total VTE $(n=31)$

\begin{tabular}{ccccc} 
Threshold & Sensitivity & Specificity & PPV & NPV \\
\hline$\geq 2000 \mathrm{ng} / \mathrm{mL}$ & 38.7 & 84.1 & 23.5 & 91.6 \\
$\geq 3000 \mathrm{ng} / \mathrm{mL}$ & 32.3 & 87.8 & 25.0 & 91.1 \\
\hline
\end{tabular}

4. VTE $<14$ days from admission $(n=23)$

\begin{tabular}{ccccc} 
Threshold & Sensitivity & Specificity & PPV & NPV \\
\hline$\geq 2000 \mathrm{ng} / \mathrm{mL}$ & 43.5 & 83.8 & 19.6 & 94.2 \\
$\geq 3000 \mathrm{ng} / \mathrm{mL}$ & 34.8 & 87.4 & 20.0 & 93.6
\end{tabular}

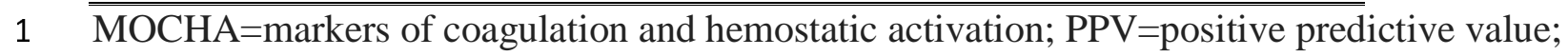

2 NPV=negative predictive value; VTE=venous thromboembolism. 